Comparative Philosophy Volume 12, No. 2 (2021): 103-124

Open Access / ISSN 2151-6014 / www.comparativephilosophy.org

https://doi.org/10.31979/2151-6014(2021).120208

\title{
THREE BUDDHIST DISTINCTIONS OF GREAT CONSEQUENCE FOR CROSS-CULTURAL PHILOSOPHY OF PERSONAL IDENTITY
}

\author{
ANTOINE PANAÏOTI
}

\begin{abstract}
This paper seeks to lay down the theoretical groundwork for the emergence of holistic cross-cultural philosophical investigations of personal identity - investigations that approach the theoretical, phenomenological, psychological, and practical-ethical dimensions of selfhood as indissociable. My strategy is to discuss three closely connected conceptual distinctions that the Buddhist approach to personal identity urges us to draw, and a lucid understanding of which is essential for the emergence of appropriately comprehensive and thus genuinely cosmopolitan discussions at the cross-road between Western and Buddhist philosophical traditions. The first, primary distinction is that between the "visceral sense of self" (VSS) and the "substance view of self" (SVS). This in turn gives rise to two derivative distinctions, namely between "harbouring VSS" and "believing SVS", and between "overcoming VSS" and "rejecting SVS". After discussing these distinctions, I consider and respond to three philosophical objections to features of Buddhist approach to selfhood that are thrown into sharper relief when attention is paid to these three distinctions. I then discuss some of the ways the foregoing may inform research in cross-cultural philosophy of personal identity. This discussion focuses on: (1) the primacy of the first-person stance in matters of personal identity; (2) the relationship between numerical identity and narrative identity; (3) interdisciplinarity in the study of selfhood; and (4) personal identity and egoism.
\end{abstract}

Keywords: Buddhist philosophy, cross-cultural philosophy, egoism, first-person stance, interdisciplinarity, personal identity, substance-self

\section{INTRODUCTION}

The substance view of the self has it that the synchronic and diachronic unity of the socalled person - shorthand, in this context, for the subject of experience, thinker of thoughts, and agent of action - require the enduring presence of some kind of simple personal substance. As is well known, the substance-self has been the object of philosophical critique for more than two millennia in various Buddhist traditions. A

PANAÏOTI, ANTOINE: Assistant Professor of Philosophy, Ryerson University, Canada. Email: apanaioti@ryerson.ca 
sizable share of Western researchers whose work touches upon personal identity in philosophy and cognitive neuroscience now agree in rejecting the substance view of the self. Contemporary Western philosophy and science thus seem to be converging with traditional Buddhist thought.

Buddhist critiques of the substance theory of the self, however, are only one component of a broader program of cognitive, affective and behavioural training targeting the deeper, pre-theoretical roots of human beings' confusion regarding their ontological status. ${ }^{1}$ There is no analogue for such a broader, holistic program in contemporary Western culture. On the contrary, in much of contemporary Western work on personal identity, a sharp boundary is drawn between the domain of the strictly theoretical ("philosophy proper"), on the one hand, and the domain of the empirical, practical and ethico-existential (psychology, cognitive neuroscience, "therapy"), on the other. Western and Buddhist approaches to the philosophical study of personal identity are thus embedded in markedly different paradigms (Panaïoti 2015). Failure to address this metaphilosophical conundrum has impeded the emergence of appropriately holistic and thus genuinely cosmopolitan cross-cultural philosophical investigations that not only consider the theoretical dimensions of Buddhist reflections on selfhood, but also recognise their phenomenological, psychological, and practical-ethical dimensions as indissociable from these. ${ }^{2}$

This paper aims to lay down the theoretical groundwork for the development of such cross-cultural investigations by examining distinctive aspects of Buddhist approaches to personal identity ${ }^{3}$ as a problem at once theoretical, psychological, existential, and ethical. More specifically, I will explore three closely connected conceptual distinctions, which, I submit, are crucial to understanding the Buddhist approach to personal identity, and thus also to engaging Buddhist traditions in the context of appropriately comprehensive cross-cultural philosophical discussions. After stating these, then examining each in turn in sections 2 to 5 of this paper, I will, in section 6, consider and respond to three philosophical objections to approaching the problem selfhood as Buddhist traditions do. In section 7, I close with a discussion of some of the consequences of the foregoing for cross-cultural philosophy of personal identity. My discussion focuses on: (1) the primacy of the first-person stance in matters

\footnotetext{
${ }^{1}$ For two recent philosophical discussions of Buddhism's ambition to not merely challenge a false belief, but to operate a kind of reformatting of the mind, see Albahari 2014 and Struhl 2020.

${ }^{2}$ Recent work on Buddhist philosophy as a 'way of life' à la Pierre Hadot (1981) represents a step in the right direction (see, in particular, the essays collected in Fiordalis (ed.) 2018), but the emergence of the kind of comprehensive or holistic cross-cultural philosophy program I am calling for here will require moving beyond understanding Buddhist thought as similar in kind and spirit to Hellenistic philosophy and more directly critiquing the disjunctive "philosophy versus therapy" dichotomy on which the selfunderstanding of contemporary mainstream Anglo-American philosophy is grounded.

${ }^{3}$ Though the primary sources I use in this paper are texts drawn from South Asian Buddhist traditions, the account I present here is by no means specific to any particular Buddhist philosophical tradition. It is meant to point to what just about all of these traditions have in common as regards their general approach to the problem of selfhood. Thus, though diverse Buddhist traditions approach this problem in slightly different ways, in what follows I will use the singular phrase 'the Buddhist approach to personal identity'.
} 
of personal identity; (2) the relationship between numerical identity and narrative identity; (3) interdisciplinarity in the study of selfhood; and (4) personal identity and egoism.

\section{THE THREE DISTINCTIONS}

An important tenet of Buddhist thought is that ordinary persons' professed beliefs concerning personal identity — which, when articulated, overwhelmingly tend to involve some pre-theoretical version of the substance view of the self - are little more than the surface expression of a more deep-seated, pre-reflective ontology of self. Buddhists also assert that this pre-reflective ontological commitment to one's own existence as an enduring and fundamentally unchanging entity bears strong connections to a number of self-regarding cognitive, affective, and behavioural dispositions. Personal identity, on the Buddhist account, is thus first and foremost a deeply personal affair - it is a matter of how I feel, not to say of how it feels to be an "I" for most people, most of the time - and only derivatively the object of a theoretical position.

To make sense of Buddhist views on personal identity, we must thus set out three important conceptual distinctions, which have not been systematically theorised in previous literature. The first, primary distinction is that between the "Visceral Sense of Self" (henceforth VSS), on the one hand, and the "Substance View of Self" (henceforth SVS), on the other. ${ }^{4}$ This distinction in turn gives rise to two further, derivative distinctions, namely that between "harbouring VSS" and "believing SVS" and that between "overcoming VSS" and "rejecting SVS".

In the three sections that follow, I examine each of these distinctions in turn, pointing both to what differentiates the two terms of each distinction and to the ways in which they are related. Why these distinctions, though not expressly theorised so far,

\footnotetext{
${ }^{4}$ VSS and SVS roughly correspond to what Pāli texts describe as the asmimāna (literally: " 'I-am' (asmi) conceit (māna), also rendered as the ahamkāramamañkāramānānusaya, i.e., "the tendency (anusaya) to the 'I'- and 'mine'- principle (ahamkāra-mamañkära) [related] conceit"; for an in-depth discussion of this concept in Theravāda Buddhism, see Collins 1982, 94-5 and 100-3), on the one hand, and the ätmavāda (literally: "the philosophical doctrine (vāda) of self (ätman)"), on the other. The asmimanna is primitive and pre-reflective, whereas the $\bar{a} t m a v \bar{a} d a$ is the result of explicit philosophical theorising. What Pāli texts dubb the sakkāyadițthi (literally: "the view (dițthi) of individuality (sakkāya)") seems to occupy a middling position between the two; it is part of sentient beings' default mode and thus prereflective, yet also consciously accessible and discursively expressible as a 'view'. The fourth to fifth century Indian Buddhist philosopher Vasubandhu thus distinguishes between a "natural" or "spontaneous" (sahajā) satkāyadrșți and a "reflective" (vikalpitā) satkāyadrș̦ti (Abhidharmakośabhāṣya, 290; see, in this connection, the account Michel Hulin develops on the basis of Vasubandhu's distinction at 1978, 46ff). Mapped onto Vasubandhu's model, VSS corresponds to sahajā satkāyadrștii, while SVS corresponds to vikalpitā satkāyadrști . The fourteenth century Tibetan Buddhist philosopher Tsong kha pa, finally, makes a similar distinction when he contrasts the self qua "referent object" of "innate confusion" from the kinds of "imaginary constructs" that arise as a result of "acquired confusion" and thus exists "only among those who advocate philosophical tenets" $(2004,211)$. This paper being philosophical as opposed to exegetical, I will not directly take up what little explicit theoretical discussion of these and related distinctions may be found in South Asian and Tibetan texts, and focus instead on conceptual clarification.
} 
are essential to gaining a lucid understanding of what the Buddhist approach to selfhood involves will emerge in the course of the discussion.

\section{VSS VERSUS SVS}

VSS and SVS may be distinguished on seven closely interrelated counts.

VSS is:

(1) first-personal and phenomenological in that it concerns my own person - its "object" is not personal identity in general, but rather the manner of existing of the person who I am alone - and in that it has a rich and distinctive phenomenological texture - i.e., though it is possible that not everyone "experiences" it in exactly the same way, "what it is like" to harbour VSS is one of its essential aspects;

(2) primarily experiential in that, though it does have representational components that are consciously accessible through introspection, VSS is first and foremost a matter of how I feel — viz., I feel or sense ${ }^{5}$ that, throughout my life, I have been, currently am, and will continue to be the self-same enduring owner of my body and mind, subject of my consciousness, thinker of my thoughts, agent of my actions, etc.;

(3) pre-reflective in that it emerges independently of any reflection on such questions as "What kind of thing am I?", "What makes me the same person through time?", etc.;

(4) pre-theoretical in that it is prior to any explicit theoretical propositional attitude with truth-bearing content of the form "My identity over time involves..." or "The necessary and sufficient conditions for my enduring existence through time are..." - to be clear, VSS does have representational components (the content of which may go something like "I have this body, these thoughts, these memories, etc.", or "It is I who started attending elementary school in 1990 , who is presently writing this sentence, and who will someday die"), but the abstract views about personal identity that result from generalisation on the basis of such propositional attitudes tend not to be obvious to those who harbour VSS until they formally reflect on these matters;

(5) intrinsically affect-laden and action-prompting in that it is in large part constituted by dispositions for self-regarding affective and behavioural responses to a broad set of subject-internal and -external stimuli - more precisely, Buddhists regard VSS as being co-variant with (a) the visceral sense of self-importance that fuels what I shall call "character egoism", i.e., the propensity consistently to prioritise my own interests over

\footnotetext{
${ }^{5}$ In her discussion of what she dubs the "sense of self", Miri Albahari speaks of this sense as being analogous to the "sense of danger". She writes: "One can have a sense of danger or insecurity without obvious input from a particular sense organ - which well suits the case of the self in question. The notion thus captures something more cognitive (as opposed to perceptual); a subjective or conscious impression of some sort" $(2006,18)$. Unlike what I propose to do here, Albahari distinguishes between the "sense of self" and the "self qua entity" per se (cf. commitment to a philosophical view about selfhood, viz., SVS).
} 
other persons' interests in practical deliberation (cf. psychological/ethical/rational egoism as philosophical theories), (b) a large set of such other - arguably derivative harmful self-regarding affects as greed, envy, possessiveness, hostility to what appears threatening, apathy vis-à-vis what "doesn't concern $m e$ ", anxiety, pride, jealousy, fear of death, etc., together with the disposition to allow these feelings to guide one's actions, and (c) a disposition to form and aggressively defend (generally in the context of debate) various strongly held beliefs (political, metaphysical, religious, and otherwise), taken to be essential to my "core identity" (in the qualitative - or narrative — sense of the term) and that are therefore invested with a strong affective charge;

(6) gradient in that harbouring VSS is really a stock-phrase covering a wide spectrum of cases ranging from (a) being possessed of full-bodied VSS (complete with its representational, affective, and behavioural components), through (b) no longer holding the beliefs that correspond to VSS's representational components (see (4), above, for examples of such beliefs), yet continuing to harbour the deep-seated sense of being numerically identical through time as well as at least some of the self-regarding dispositions that constitute VSS's affective and behavioural components, all the way to (c) no longer holding the beliefs corresponding to the representational components of VSS and having overcome almost all of the self-regarding behavioural and affective dispositions that co-constitute VSS (but the most tenacious and automatic), yet continuing to be possessed of the deep-seated sense of being numerically identical through time; ${ }^{6}$ and

(7) quasi-universal in that it is something of a "natural standpoint" or "original condition" for all sentient beings.

In contrast, SVS is:

(1) third-personal and non-situated in that it concerns all persons at all times, not just my own person, and in that it is devoid of a distinctive phenomenological texture certainly, believing SVS has some "what it is like"-ness to it, but there is no reason to think that its phenomenological texture is different to that of being committed to any other philosophical doctrine;

(2) strictly cognitive in that it just consists in a particular doctrine, viz., "What makes a person a unified self at any given time and the same person over time is the enduring existence of this person's substance-self";

(3) reflection-dependent in that it is the product of sustained reflection, typically of a philosophical, theological, or (armchair) psychological character;

(4) theoretical in that it is a propositional attitude with truth-bearing content which concerns personal identity as a general question;

${ }^{6}$ Thus, the Buddhist monk Khemaka reportedly claimed that though he recognised that no 'I' could be located or identified in the stream of psychophysical events, he nevertheless experienced a sense of ' $I$ am' in connection to the mind-body complex (Samyuttanikāya III.128). 
neither intrinsically affect-laden nor intrinsically action-prompting in that, in and of itself, belief in SVS is affectively neutral and devoid of motivational charge - as is the case with belief in any philosophical doctrine, belief in SVS may be bound up with dispositions for certain affective responses by virtue of contingent person- or community-specific associations, and may guide action when it is embedded in certain justificatory frameworks, but, considered in isolation, it neither elicits emotional responses nor prompts action;

all-or-nothing in that one either believes or disbelieves $\mathrm{SVS} ;{ }^{7}$ and

(7) relatively localised in that it is a specialist doctrine with a circulation that is limited to a relatively small community of philosophers, psychologists, and religious preachers, together with their audiences.

Enlightening parallels can be drawn between the VSS-SVS distinction and two other sets of attitudes. Consider, first, the distinction between the visceral sense of being a free-willed agent and the belief in the philosophical doctrine of libertarian free will. ${ }^{8}$ The differences between these are of the same kind as the differences between VSS and SVS. Consider, second, the distinction between the visceral sense that I matter more than others, that my interests invariably outweigh those of other sentient beings, etc. - i.e., character egoism — and the belief that rational egoism is the correct theory in the philosophy of practical rationality. The differences between these are, again, of the same kind as the differences between VSS and SVS.

\section{HARBOURING VSS VERSUS BELIEVING SVS}

These parallels help bring into relief important aspects of the relationship between VSS and SVS, which in turn point to the second Buddhist distinction I wish to establish, namely that between harbouring VSS and believing SVS.

\footnotetext{
${ }^{7}$ As regards belief in philosophical doctrines, then, Buddhist thought does not sit well with Eric Schwitzgebel's dispositional account of belief, which is designed to address the so-called in-between cases where a subject seems neither fully to believe nor fully to disbelieve a given belief (2002). Schwitzgebel's dispositionalism might be applicable to something like VSS, but, for Buddhists, this is not, precisely, a belief. A contemporary development at the intersection between philosophy of psychology and epistemology that arguably helps to make better sense of Buddhist philosophy of personal identity is Tamar Gendler's (somewhat controversial) distinction between alief and belief (2008). Mapping the Buddhist distinction between VSS and SVS onto Gendler's model, we get something like this: VSS as a whole belongs to the category of dispositional, more evidence- and reasoning-resistant aliefs, while both SVS and those propositional attitudes that make up the representational components of VSS belong to the category of belief.

${ }^{8}$ See, in this connection, Albahari 2006, 17, although (as stated above, at the end of footnote 5), what she strives to distinguish is the "sense of self" versus the "self qua entity" itself, and thus, along similar lines, the "sense of free will" versus "libertarian free will" itself. For a treatment closer to my own, see Strawson 2008, 111-2.
} 
The relationship between VSS and SVS may be considered from two different angles. One may, to begin, claim something like this: Just as the sense of being a free willed agent provides the philosophical doctrine of libertarian free will with strong intuitive appeal, or just as character egoism provides the philosophical doctrine of rational egoism with strong intuitive appeal, so too does VSS provide SVS with strong intuitive appeal. Alternatively, one may make a slightly different claim: Just as the philosophical doctrine of libertarian free will consists in the theoretical articulation or generalisation of the representational components of the sense of being a free-willed agent, and just as rational egoism consists in the theoretical articulation or generalisation of the representational components of character egoism, so too does the content of SVS consist in the theoretical articulation or generalisation of the representational components of VSS. We have two claims here, then, namely: (1) that VSS helps explain the intuitive appeal of SVS; and (2) that the prevalence of VSS helps explain the emergence of SVS. Neither of these explanatory claims, of course, suggest that VSS provides any evidence for the truth of - or justifies - SVS.

In light of what I said in section 3, moreover, it is obvious that harbouring VSS does not entail believing SVS. One may feel and think that one is the "same person" through time, yet hold no particular philosophical view about personal identity. Nevertheless, because it has easily generalisable representational components, harbouring VSS does typically involve a strong disposition to believe SVS if and when the appropriate conditions are met, e.g., when one receives philosophical training, or when one is exposed to certain religious teachings. The fact that harbouring VSS is gradient, allows us to venture a more fine-grained hypothesis. On this hypothesis, the extent to which harbouring VSS is accompanied by a disposition to believe SVS is a function of how strongly a given subject harbours VSS. Thus, the weaker the grip of VSS on a particular subject, the lesser her disposition to hold SVS - and vice versa.

It will be worthwhile, in this connection, to say a few words on Buddhist attitudes to philosophical commitment to SVS. When pressed to think about the issue systematically for the first time, people who harbour VSS and are minimally rational — i.e., the vast majority of people - are very likely to throw their support behind something like SVS. Most "philosophically trained" people (inclusive, here, of people who have been exposed to reasoned religious thought), the Buddhist account predicts, will thus initially hold SVS when they begin thinking about personal identity. And most such people will continue to do so even after considering powerful objections to SVS, for the simple reason that "most such people" are, by definition, ordinary people harbouring VSS at least to some degree.

Now, Buddhist philosophers regard SVS as plainly contrary to reason (yukti) they hold arguments against SVS to be compelling, arguments for SVS fallacious, alternative views of the nature persons more economical (laghu) and consequent (upapanna) than those that rely on the substance-self postulate, and the supposed problematic theoretical and ethical implications of rejecting SVS dependent on 
question-begging assumptions. ${ }^{9}$ But Buddhist philosophers are also aware that most people will be reluctant to abandon SVS, and seek to justify their stance by claiming that they find arguments in favour of SVS compelling, alternative views of the nature of persons implausible or inadequate, and/or the theoretical or ethical implications of rejecting SVS too problematic for this view to be seriously called into question. Such justification for holding fast to SVS, however, Buddhists regard as psychologically superficial - i.e., as the work of what we now call rationalisation. No matter how they may justify their beliefs, what really explains such persons' judgments concerning what is or is not rationally compelling in matters of personal identity is that they harbour VSS. To account for the unreason exhibited by most philosophically trained persons' persistence in believing SVS in spite of everything that speaks against it, Buddhists tend to go down what Steven Collins describes as the ad hominem route, ${ }^{10}$ i.e., they appeal to the overpowering psychological force of VSS as the primary explanatory factor contributing to such intellectual stubbornness.

Strong attachment to traditional religious doctrines or to the tenets of a philosophical 'system' (darśana) are of course recognised as an explanatory factor, but these are generally conceived of as proximate causes, with harbouring VSS as the root cause. As mentioned above, an important aspect of harbouring VSS is precisely the disposition to form and aggressively defend rigid "positions" (drsțilpakșa) and "philosophical doctrines" ( $v \bar{a} d a)$ that, as seemingly essential features of one's "core identity", are invested with a strong affective charge. Most prominent and most firmly held amongst these, we can now see, are philosophical theses - metaphysical, epistemological, and ethical — which precisely concern, directly or indirectly, personal identity. VSS is not just reason-resistant, then; it reinforces itself by hijacking persons' rational faculties.

It follows from the foregoing that, though one may harbour VSS without believing SVS, genuinely believing SVS entails harbouring VSS. I say 'genuinely' because puzzlingly — some Buddhist texts suggest that those who no longer harbour VSS may, in some circumstances, incite others to believe SVS. This may give the impression that they believe SVS, though this impression is of course misleading. How and why Buddhists who have done away with VSS may at times propound SVS will become clearer in the next section of this paper.

\section{OVERCOMING VSS VERSUS REJECTING SVS}

The third and final distinction I shall be discussing is that between overcoming VSS and rejecting SVS.

Overcoming VSS is the outcome of a holistic process involving changes in my beliefs as well as more psychologically far-reaching affective and behavioural changes

\footnotetext{
${ }^{9}$ For a philosophically elegant and philologically rigorous survey of the main arguments against the existence of the substance-self (ätman; Pāli: attan) in Pāli canonical literature, see Collins 1982, 95-110.

${ }^{10}$ Collins 1982: 117.
} 
in my way of experiencing self and world. Rejecting SVS, in contrast, involves nothing more than rejecting a doctrine concerning personal identity.

Buddhist philosophy and practice are designed to assist people in overcoming VSS - a goal, it is claimed, that the subject may attain only by herself, Buddhist teachers being mere facilitators. ${ }^{11}$ For Buddhists, overcoming VSS represents the supreme achievement available to sentient beings, the ultimate mark of wisdom (prajña ), and the fount of the highest virtue, namely boundless, universal compassion (mahākarun $\bar{a}$ ). It is also said to bear a deep connection with the complete cessation of the subject's own suffering (duhkhanirodha), which is a key goal of the Buddhist path. And while Buddhist treatises on metaphysics present arguments against SVS, and seek to develop alternative accounts of persons as continua rather than bearers of a substance-self, Buddhists regard rejecting SVS in favour of a more deflationist view of the nature of persons as a mere prelude to the truly important and far harder work of overcoming VSS. ${ }^{12}$ This is because, for reasons which should now be obvious, rejecting SVS is by no means sufficient for overcoming VSS, nor even for ridding oneself of its representational or propositional components (even though these do not cohere with the falsity of SVS). ${ }^{13}$ As a rule, it represents but a first step in the right direction.

I say 'as a rule' because an important qualification is in order here. Indeed, there exist influential Buddhist texts that suggest that, for certain types of people at critical junctures, rejecting SVS is counter-productive in that it would likely reinforce rather than undermine VSS. This calls for some explanation. A bit of context, to begin. There existed in Ancient and Classical India a school known as the Cārvāka or Lokāyata, which appears to have been fairly popular amongst merchants, commoners and some aristocrats. The Laukāyatika were atheistic, materialistic, and committed to what Buddhist authors describe as an ethos of imprudent, short-termist, and morally inconsiderate hedonism. According to Buddhist texts, their philosophical view concerning personal identity — which they purported to represent something like the "everyday" common sense view — was that the self is a real entity, albeit a very shortlived one. The implication the Laukāyatika apparently drew from their view of personal identity is that the ground for moral accountability is much more limited than most

\footnotetext{
${ }^{11}$ This is true even of Pure Land Buddhism, a quasi-theistic cult in which practitioners invoke the Buddha Amitābha's compassion in the hope that he will cause them to be reborn in one of his so-called pure lands. Once there, the practitioner will be able to make progress on the Buddhist path, a task regarded as practically impossible in the degenerate quarters of the universe in which you and I live.

${ }_{12}$ Thus, in the Pāli canon, rejecting the sakkayyaditthi is described as the first of the ten 'fetters' (samyojana) that must be removed to attain to Buddhist sainthood (Ainguttaranikayya V.17), the idea being that this fetter is the easiest to remove of the ten.

${ }^{13}$ As Derek Parfit observes, even those who deny that personal identity over time holds by virtue of some 'further fact' beyond relations of psychophysical connectedness and continuity — namely some further fact about the self qua separate entity or substance and its endurance through time - tend to continue to hold beliefs concerning their own death or survival which, if true, would require some version of the substance view of the self to be true $(1982,228,237 ; 1984, i x, 281,346,445 ; 1986,834-35 ; 1998$, 146-47; 1999, 217).
} 
other philosophers and religious predicators teach. ${ }^{14}$ Now, some Buddhist texts give expression to the following fear: Persuade a Laukāyatika or someone who is likely easily to be wooed by them that she is in fact entirely bereft of a personal substance, and there is a high risk that she will wrongly infer from this that both morality and prudence are entirely without ground, because it will not be she tomorrow who will suffer the consequences of today's actions, ${ }^{15}$ because those whom she harms today will no longer exist tomorrow, etc. ${ }^{16}$ Such a person, in short, uses the defeat of SVS as a way of rationalising the heedless (character) egoism with which VSS is tightly connected, thereby strengthening both. Critiquing SVS has indirectly reinforced VSS; the Buddhist teaching has backfired.

Some Buddhist texts thus make reference to a pedagogical principle followed by wise teachers: For people susceptible of embracing the Laukāyatika teaching, ordinary beliefs about personal identity ought not to be challenged in the initial stages of instruction, even though rejecting SVS will eventually be necessary on the path to overcoming VSS. ${ }^{17}$ The sixth century Indian Buddhist philosopher Candrakirti goes further than this. The best way to help such people eventually to overcome VSS is first to encourage them to identify more strongly with their future selves by promoting the view that the self is an indestructible substance. ${ }^{18}$ On Candrakīrti's view, then, there exists a certain class of people who ought to be encouraged to believe SVS, even though these same people, when they eventually attain a certain state of development, will need to reject SVS if they are to make any further progress.

Buddhist attitudes with respect to the rejection of SVS are also ambiguous at the other end of the spectrum - i.e., when it comes to people who are not exceptionally foolish, but exceptionally wise. Indeed, Buddhists hold that rejecting SVS in favour of some more sophisticated view of personhood can outlive its utility, and can even turn into something harmful.

\footnotetext{
${ }^{14}$ Here and in what follows, I deliberately alter the details of the disagreement between Laukāyatikas and Buddhists (as described by the latter — we have no extant Laukāyatika texts) such as to bypass the (from a philosophical perspective) contingent fact that the debate was initially framed in terms of whether or not transmigration or 'rebirth' (punarjanman) and natural moral retribution (karman) were indeed facts of life (and death). A more faithful historical account would read as follows. The Laukāyatikas taught that the self exists, but that it is destroyed at the moment of death, the implication being that, from the moment of the agent's death onward, there is no one to whom the karmic effects of past actions could accrue. The Buddhists taught that though no substance-self exists, persons qua continua made up of functionally integrated physical and mental events do in a sense survive their deaths (in the form of a very subtle body endowed with latent seeds of character dispositions) and are born anew in the cycle of transmigration known as samsāra, such that none fails to suffer/enjoy the karmic effects of their past actions. The essence of the ethical disagreement between Laukāyatikas and Buddhists, however, can be captured without reference to rebirth and karman, under which form it will likely be easier to digest for a Western audience. Hence my adaption of this dispute in less metaphysically committed terms.

15 The Buddha is said to have described this belief as follows: "One [person] acts, another experiences the results” (Saṃyuttanikāya II.20: añño karoti añ̃no pațisaṃvediyati).

${ }^{16}$ Parfit raises similar concerns as regards the implications of rejecting SVS at 1984, 307-11.

${ }^{17}$ See the "Discourse to Ānanda" at Samyuttanikāya IV.400.

${ }^{18}$ Prasannapadā, Commentary on Mūlamadhyamakasūtra XVIII.6.
} 
How can we make sense of this? Well, recall that one of the most resilient aspects of VSS is precisely the disposition to form and develop strong attachment to views. Grasping at some complex non-substance view of personal identity as the correct theory of personal identity or even just at the falsity of SVS as the correct theoretical stance (however purely "negative" or "critical" this stance may be), Buddhists point out, is in fact both symptomatic of and fuel for VSS, and more specifically for some of its basic-most affective and behavioural components, such as pride, argumentative combativeness, and related character flaws. In the final analysis, rejecting SVS and embracing a view of persons as dependently co-arisen continua is but a tool skilfully to be used to help begin to dismantle VSS; it is not to be clung to as a theoretical position in its own right. It is a discursive intervention, the propositional content of which has no independent value of its own. ${ }^{19}$ Thus, neither the claim "The substanceself exists" nor the claim "The substance-self does not exist" are to be endorsed by the truly discerning person. ${ }^{20}$ The first claim, though it initially ought to be regarded as false across the board, should eventually be understood as meaningless (in so far as the "substance-self" is not so much a concept as discursively crystallised existential confusion). The second claim is not so much false as appropriate only as a corrective, the purpose of which is merely to help undermine the first, after which point it becomes redundant and ought to be allowed to fade out of consciousness, lest it be clung to as a new basis for delusional identity-construction. ${ }^{21}$ Rejecting SVS, accordingly, is like a medicine, which risks poisoning the patient if she continues to consume it after healing is well under way. ${ }^{22}$ While Buddhists regard rejecting SVS as necessary (though not sufficient) for overcoming VSS, then, belief in the falsity of SVS must eventually also

\footnotetext{
19 While this position is more readily associated with the anti-foundationalist and anti-realist Madhyamaka school of classical Indian Mahāyāna Buddhist philosophy, it is in fact frequently evoked in the (relatively ancient) Pāli Canon. See, in this connection, Gómez' reading of certain poems in the Suttanipāta collection (1976).

${ }^{20}$ Prasannapadā, Commentary on Mūlamadhyamakasūtra XVIII.6. It should be noted that the notion that denying the existence of the substance-self need not imply affirming its non-existence and other such logical moves led some Buddhist philosophers to distinguish between different types of negation and more specifically to theorise non-implicational forms of negation (prasajya-pratisedha), i.e., propositional negation that does not entail the truth of the contrary proposition. On this point, see Ruegg 1977 and Westerhoff 2009, Chapter 3.

${ }^{21}$ The self-effacing character of Buddhist philosophy of personal identity is reminiscent of what Wittgenstein seems to have had in mind when he presents the "ladder" analogy at the baffling close of his Tractatus Logico-philosophicus (1922; proposition 6.54).

${ }^{22}$ The (largely marginal) Indian Buddhist tradition that finds its primary articulation in the Mahāyāna Mahäparinirvānasütra develops an idiosyncratic variant on this common simile. This text describes the injunction to reject SVS as similar to a doctor's instruction not to feed a baby breast milk while it is consuming a particular type of medicine, here a stand-in for Buddhist therapeutic interventions designed to undermine the visceral sense of being an individuated substance-self. Once the treatment has been completed, the life-sustaining milk (of SVS) should be allowed to flow again as it is revealed to the student that her true identity is grounded in a collective or shared personal substance, namely the "Buddha-nature" (see Yamamoto (trans.) 1973-5). This Buddhist tradition, committed as it is to a revised SVS, is the exception that confirms the rule. For more details on these surprising developments in Buddhist philosophy of personal identity in India and Tibet, see Williams 1989, Chapter 5.
} 
be relinquished. Those who have overcome VSS, in other words, believe neither that SVS is true nor that it is false. ${ }^{23}$

\section{THREE OBJECTIONS, THREE REPLIES}

Strictly speaking, all I have shown so far is that the Buddhist approach to personal identity is best understood in light of three closely connected conceptual distinctions, and that these can be cashed in technical philosophical terms. But this is hardly sufficient to establish that this type of approach to personal identity is philosophically defensible, let alone that it can do anything for us in philosophy today. In fact, mainstream philosophers may feel that the main upshot of my discussion so far is that Buddhist views on personal identity are more philosophically confused then they are made to seem when presented and discussed as metaphysics simpliciter. Before discussing the ways in which I think Buddhists' more holistic approach to personal identity may contribute to enriching Western and cross-cultural reflections on selfhood, I thus wish to subject the Buddhist approach to critical appraisal and respond to its would-be critics. ${ }^{24}$ Let us consider, to begin, three objections to the philosophical tenability of the Buddhist approach as it reveals itself to us when it is considered through the prism of our three distinctions. These are:

(A) The numerical-narrative identity conflation objection. The Buddhist account conflates the issue of narrative identity with that of numerical identity. Whether or not they are aware of this, what Buddhists are actually targeting is a way of "narrating" the autobiographical tale in which I feature as a protagonist. More precisely, what Buddhists object to (and devise strategies to combat) are dispositions to say, think, and feel "This is me", "This is what I'm like", This is not me", "This is not what I'm like", "This is mine", "This is alien to me", etc., on the grounds that these ways of telling stories about myself bear some sort of relation to egoism and that egoism does more harm than good. The belief that I am numerically identical through time is actually a separate issue. To wit, it is conceivable that I should believe that I am numerically identical through time, yet also believe that I have good practical reasons (prudential, moral, or both) to adopt less rigid a self-schema, weave my autobiographical stories in less black-or-white, selfreferential ways, and strive to be less egocentric in part by altering the form and content of my autobiographical narratives. But this need not require me to change my view about the necessary and sufficient conditions for personal identity through time. This reveals that the metaphysical issue of numerical identity is in fact orthogonal to the questions with which the Buddhists are really concerned. The case of inconsistent Buddhist

\footnotetext{
${ }^{23}$ Nevertheless, such Buddhist sages would remain disposed to propround certain teachings concerning SVS in circumstances they deem appropriate, including, in many cases, the teaching that SVS is false.

${ }^{24}$ I say 'would-be critics' because I am not aware of anyone, so far, formulating the types of objections considered below. This, I presume, is simply because the features of Buddhist philosophy of personal identity that are pointed to in said objections were difficult to isolate, make explicit, and focus upon for as long as the distinctions discussed earlier in this paper were not systematically theorised. One may say, then, that my main motive in this section of the paper is to pre-emptively push back against the kinds of critique the Buddhist approach to personal identity becomes vulnerable to when it discloses itself in its properly holistic aspect (cf. when it is (artificially) presented as mere 'theory').
} 
instruction to various types of people makes this very clear. If he follows Candrakīrti's advice, the Buddhist sage will teach a Laukāyatika that the self is an indestructible numerically identical substance in the hope that this will motivate him to develop greater prudential and moral concern. But to others she will teach that there is no substance-self. This shows that the metaphysics or nature of selfhood are not at all the issue here, and that what Buddhism is actually concerned with are only theory-independent psychological conditions for human thriving that can be cashed out in "narrative" terms alone. The case of the Buddhist sage who believes neither that there exists nor that there does not exist a substance-self suggests the same thing, namely that the question of numerical identity is not one which Buddhism is actually concerned with. So the Buddhist account is vitiated by some sort of conceptual confusion, the result or symptom of which is to conflate numerical and narrative identity. The Buddhist account, as a consequence, is philosophically untenable.

(B) The correlation-causation confusion objection. There might be empirical support for the idea that people who are more egoistic have more rigid self-schemata and erect stronger boundaries between self and other. It may even be true that having a more rigid selfschema and a stronger sense of a boundary between self and other is constitutive of egoism. There might also be empirical support for the idea that, as a rule, when an ordinary person suffers physical hardship or psychological turmoil, she tends to harbour a more rigid self-schema, to erect stronger boundaries between self and other, to harbour more strongly self-referential and egoistic dispositions, etc., than she does normally. Conversely, there might be empirical support for the idea that most people have less rigid self-schemata, have a weaker sense of a boundary between self and not-self, are less egoistic, etc., when they are free from physical and/or psychological suffering. But these correlations by no means imply that there exists the kind of causal relation Buddhists apparently think are exhibited here. These correlations, in other words, give us no reason to believe that the sense of self is somehow "responsible" for existential suffering and egoism. A more plausible take-away would be that the kind of pre-reflective ontological rigidity as regards the "sense of self" to which Buddhists call attention is epiphenomenal - which squarely contradicts the causal story the Buddhists are trying to push. It would appear, then, that the notion that overcoming the visceral sense of self will bring about a reduction in existential suffering and egoism is predicated on wrongly inferring causation from correlation. The simple, unexciting truth might simply be that we have a stronger sense of self in certain circumstances and a weaker sense of self - or, in positive terms, a stronger sense of "flow" - in other circumstances. But, in and of itself, this tells us strictly nothing about the relationship between the philosophy of personal identity and such practical-ethical questions as how to lead better, more fulfilling lives. The Buddhist account, it turns out, rests on the elementary conceptual mistake of inferring causation from correlation. As such, it lacks philosophical credibility.

(C) The logocidal implications objection. The implicit view about rationality which underwrites the Buddhist account is one which gives appeal to reason little to no weight in changing people's minds and hearts. Buddhists seem to think that there is little more to reasoning than rationalisation - the example of the arch-hedonist Laukāyatika's response to rejecting the substance-view of the self makes this very clear indeed - and that even correct theoretical beliefs should ultimately be jettisoned for fear that one will 
become unhealthily emotionally attached to them or that they will "cramp one's style". Philosophical reflection alone is said not to be enough to realise the truth, which, at the end of the day, can only be achieved by means of training and practice. And, as though this were not enough, the conception of ultimate wisdom on offer in Buddhism involves discarding all philosophical views on selfhood. Such an ideal of wisdom is at best paralogical. The Buddhist account is not philosophy; it is non-empirical psychology, or, worse, mysticism, complete with a deflationary view of reason that pulls the carpet from under philosophy's feet. The Buddhist account, in short, has logocidal implications. As such, the question of its philosophical tenability is beside the point — the Buddhist account condemns the "philosophical approach" itself, and, as such, takes itself out of the game of genuine philosophical reflection from the very outset. This precludes any genuinely comparative discussion, let alone fruitful cross-cultural investigation.

To these three objections I reply as follows:

(A') Response to the numerical-narrative identity conflation objection. The conflation objection is question begging. It is founded on an assumption to which Buddhists are not committed, and which the Buddhist approach in fact gives us reasons to call into question. The accusation of conflating separate issues that bear no necessary connection to one another - in this context, the issue of narrative identity and that of numerical identity — can only do damage if it is already established or self-evident that said issues are indeed separate and unrelated. But this does not hold of the narrative versus numerical identity distinction, which does not seem to run very deep - quite the contrary. To wit, most people's autobiographical narratives are founded (at least tacitly) on an idea which may be rendered as follows: "It is $I$ who have been in existence (at least) since birth, $I$ who am currently existing, and $I$ who will continue to exist until death (and perhaps even after); and these three uses of 'I' refer to the same entity". It is hardly surprising, then, to find leading narrative identity theorist David DeGrazia declaring that narrative identity presupposes numerical identity (2005). Conversely, the case could also be made that numerical personal identity only plays a role in people's self-understanding and thus in people's lives to the extent that it is a feature of their autobiographical narratives. Claims about numerical identity, after all, can often be rephrased as claims about qualitative identity, as evidenced by Leibniz's law. ${ }^{25}$ In so far as narrative identity is a type of qualitative identity, it follows that numerical identity can also be cashed out in terms of narrative identity. To identify as the same core self through time, on this model, is just consistently to ascribe the same essential properties to one's core self in one's autobiographical narratives. The upshot is that there is something suspiciously circular here, for it seems as though, on the one hand, narrative identity as it is commonly understood formally presupposes numerical identity, while, on the other, the numerical sameness of the self is in turn established through certain types of narratives about the self. While some may argue that this lends credence to an emergentist account of selfhood, most Buddhists (along with most Kantians and phenomenologists, I would aver)

${ }^{25}$ This states that object $\mathrm{O}$ and object $\mathrm{O}^{\prime}$ are (numerically) identical iff all of the properties of $\mathrm{O}$ are also properties of $\mathrm{O}^{\prime}$. Admittedly, Leibniz' law is not meant to cover identity over time (see, on this point Baxter 1989), which is what numerical personal identity most certainly concerns, but this does not affect my basic point, which is that the distinction between qualitative and numerical identity is not as deep as is often assumed. 
would choose instead to draw the more modest conclusion that issues surrounding narrative identity and issues concerning first-personal numerical identity cannot be dissociated. Thus, it may well be that altering the form and content of my autobiographical narratives will involve changes in my ideas about and sense of numerical identity, and vice versa. In short, the Buddhist reply to the conflation objection is that it is meaningless to speak of two questions being conflated if they are really two aspects of the same basic question. As for the cases of instruction to Laukāyatika-s or of the Buddhist sage's rejection of both belief in SVS and belief in the falsity of SVS, neither of these show that the question of numerical identity is not really at issue in Buddhist philosophy of personal identity; all they show is that Buddhists were attuned to the dangers of rationalisation (in relation to those who might appeal to the absence of a substance-self to justify gross imprudence and immorality) and were aware of the round-about mechanisms by virtue of which rigid self-schemata are propped up, even amongst exceptionally insightful people. The Buddhist account, to conclude, concerns both narrative and numerical identity — and this is one of its strengths, not weaknesses.

(B') Response to the correlation-causation confusion objection. On this point, Buddhists can afford to bite the bullet, then spit out the greater part of it: Perhaps there is just a positive correlation between VSS, existential angst, and character egoism, and not causation from VSS to angst and egoism, but this implies neither that VSS is entirely epiphenomenal nor that Buddhist philosophy of personal identity has nothing to contribute to questions concerning the good life. VSS might not be the single cause of existential suffering and egoism, but it might nevertheless be a key player in a cluster of attitudes, dispositions, and affects that wax and wane together. And it is reasonable to suppose that the issue of selfhood - because it is more easily consciously accessible through introspection and is tied up with a number of propositional attitudes that are amenable to rational critique represents one of the most reliable ways, for most people, to get a firm grip on the sacred cow's horns. This is not to deny, of course, that the Buddhist path is holistic in its structure and approach - discursive critiques of SVS and of the arbitrariness of evaluative self-centredness go hand-in-hand with behavioural as well as meditative training designed more directly to tackle the affective and behavioural components of VSS. But the existence of such a holistic approach in Buddhism by no means implies that the Buddhist account fails to tell us anything of philosophical interest about how questions surrounding personal identity connect to broader psychological, phenomenological, and ethical issues. It might not do much by way of explaining the situation; but that is not its stated purpose. The purpose of Buddhist thought, instead, is adequately to describe a problematic state of affairs in such a way as to inform efficient, mindful action. Taking action on this front involves, amongst other things, the practice of meditation exercises which, as recent psychological studies show, do indeed lead to changes in self-referential thought and ways of framing my self-schema (Brewer et al. 2011; Brown et al. 2007; Farb et al. 2007; Hayes \& Plumb 2007; Heppner \& Kernis 2007; Leary \& Tate 2007). To claim that, in the absence of a clear causal relation from a confused sense of self to existential suffering and egoism, the Buddhist account has nothing to contribute to enquiry concerning personal identity and ethics, then, is to set the bar unreasonably high. Even if the Buddhist account points only to a (non-contingent) correlation - and not to a causal relation - we might nevertheless have much to gain in examining it more carefully at the cross-roads between philosophy, psychology, psychotherapy, and cognitive neuroscience. 
(C') The logocidal implications objection. This objection draws unwarranted conclusions from certain features of the Buddhist account. Buddhist thought might, relative to other philosophical traditions, be less optimistic about the role and weight of reasoning, theory, and belief-revision in the quest for the good life, but to say that the implications of these attitudes are necessarily ${ }^{26}$ logocidal goes too far. Even cumulatively, the ideas that much of reasoning is really just rationalisation parading as impartial critical appraisal, that most people are not susceptible to changing their ways on the force of arguments alone (even when they seem to have changed their minds), and that human beings have deepseated tendencies to become emotionally attached to certain philosophical views in ways that can be and often are harmful do not entail that all theory/reasoning is but rationalisation, that arguments have no role to play in changing people's ways, or that we should not seek to undermine false or meaningless beliefs, provided that we do not let the alternative beliefs thence formed turn into dogmatic idées fixes. So while it may be true that Buddhists do not regard philosophical reflection and reasoning as sufficient for the complete realisation of the truth — or wisdom — , the fact is that most Buddhist traditions regard philosophical reflection and reasoning as necessary for attaining this end. ${ }^{27}$ Only if it were first agreed that a tradition must regard dialectical reasoning as necessary and sufficient for the attainment of wisdom to be a participant in philosophical conversations would it follow that there is no room for Buddhism in contemporary philosophical discussions. But this is clearly an over-stringent criterion, which would rule out many other key players in the Western tradition — including, God forbid, David Hume. The Buddhist account does not have logocidal implications, then; and the metaphilosophical implications it does have do not justify removing it from the field of philosophical considerability.

\section{CONSEQUENCES FOR CROSS-CULTURAL PHILOSOPHY OF PERSONAL IDENTITY}

I now wish to discuss some of the consequences of the foregoing for contemporary philosophy of personal identity. These could in principle be regarded as "lessons" participants in the Western philosophical tradition could learn from Buddhist thought independently of any more substantive cross-cultural project. But it would be more fruitful and express greater responsiveness to the demands of cosmopolitanism to conceive of them instead as conditions for the emergence of genuinely cosmopolitan cross-cultural philosophical investigation — the holistic Buddhist approach to the

\footnotetext{
${ }^{26}$ I say 'necessarily' because while it seems true that some Buddhist traditions are logocidal (viz., some versions of Ch'an or Zen Buddhism), these are the exception, not the norm. What is more, the notion that reasoning is part of the problem, not the solution is underdetermined by even the most anti-realist and/or sceptical Buddhist schools' views on language, knowledge, reason, truth, and wisdom.

${ }^{27}$ The seventh century Indian Buddhist philosopher Dharmakīrti states this explicitly in the very first line of his Nyāyabindu: "all human goals [inclusive of the attainment of supreme wisdom] depend on correct knowledge" (samyagjñannapürvika sarvārthasiddhis), i.e., knowledge acquired by means of "[correct] perception" (pratyakșa) and "[cogent] inference" (anumāna). In the Tibetan tradition, Tsong khapa likewise argues that critical reasoning is essential to attaining the highest wisdom (see, in this connection, Jinpa 2002, 176-83).
} 
problem of personal identity being so different from the exclusively theoretical-cumconceptual methods, focus, and concerns of contemporary mainstream AngloAmerican philosophy as to make true dialogue between these two traditions very difficult indeed. ${ }^{28}$

First, Buddhist views on personal identity point to the primacy of the first-personal, experiential stance in matters of personal identity. Personal identity, here, primarily concerns the experiential "I", and only derivatively the "you", "s/he", "we", and "they". This is one of the upshots of identifying the more primitive VSS as the psychological and phenomenological ground of SVS as an abstract theory. Reflecting on the Buddhist approach to personal identity thus represents an invitation, perhaps even a call, for something of a more resolute "phenomenological turn" in the philosophy of personal identity, ${ }^{29}$ akin to what we have recently witnessed in philosophy of mind and philosophy of cognitive science. A more important place has to be made in philosophical enquiry into selfhood for the question of what the experience of personal identity "is like" and how changes to first-personal self-schemata affect our experience of and relation to self, world, and other. This, at any rate, is required should we wish to see the emergence of a genuine interface between Buddhist and mainstream or professional Western philosophy of personal identity.

Second, as suggested in my reply to objection (A) above, the Buddhist account of personal identity invites us to call into question any hard and fast distinction between numerical identity and narrative identity. It remains an open question whether the socalled narrative approach actually represents an alternative to more standard approaches to personal identity, which focus on numerical "sameness" or what David Hume called "perfect identity" (1739-40, SB 255). The Buddhist account suggest that this question may in fact be a variant of what Parfit, in a different context, calls an empty question $(1984,238-9)$ - i.e., a question that admits of no meaningful or conclusive answer in so far as its very articulation is expressive of conceptual confusion. To wit, Buddhist views on the mental dynamics of identity construction and the constitution of the "I" suggest — pace Schectman (1996) — that the narrative approach to personal identity provides not so much an alternative to the numerical approach as a way of describing with greater psychological and phenomenological precision the arising of the sense and notion of a numerically self-same "I" qua protagonist of my

${ }^{28}$ To wit, much of what passes for dialogue with Buddhist thought in contemporary Western academic philosophy appears to treat what is really an extremely narrow, Eurocentric, and historically contingent late modern conception of 'philosophy' (according to which 'philosophy' and 'therapy' are mutually exclusive, 'principled' commitment to views is the be all and end all of philosophical practice, etc.) as the universal and timeless concept $<$ philosophy $>$. As result, Buddhist theory's essential relation to practical concerns, therapeutic-cum-ethical orientation, and inextricability from meditation training are largely ignored or downplayed as genuinely 'philosophical' concepts, theories, and arguments are 'conceptually retrieved' from the 'supra-' or 'para-philosophical' morass in which they are embedded. There is nothing cosmopolitan about this; on the contrary, it is deeply parochial.

29 As such, the Buddhist approach lends further credence to the views advanced by such phenomenologists as Paul Ricœur (1990) and, more recently, Dan Zahavi (2005), who - for all their uneasiness with scepticism about the self - also insist on the primacy of the first-personal perspective when it comes to personal identity. 
life story. Should it be further supported and validated, this would be an important result and would open the horizon for fruitful cross-culturally informed debates.

Third, philosophical dialogue with Buddhism in matters of personal identity also requires us to break down disciplinary barriers by developing something of a hybrid approach combining conceptual, theoretical, and philosophical enquiry, on the one hand, with empirical, practical, and psychological enquiry, on the other. As regards the field of "personal identity and ethics", in particular, the role of emotions and experiential states ought more closely to be examined, especially in connection to psychological and cognitive neuroscientific studies on the effects of meditation practices that alter one's sense of self. Luckily, we already have something of a precedent for this in contemporary moral philosophy, namely the flourishing (if controversial) field of virtue ethics, which proceeds through a happy hybridisation of conceptual-philosophical and empirical-psychological-biological considerations. If holistic cross-cultural approaches to selfhood that engage Buddhist philosophical traditions are to see the light of day, something similar ought to take place in the ethics of personal identity field.

Fourth, the holistic Buddhist approach to personal identity as a problem at once philosophical, psychological, existential, and ethical helps more carefully to distinguish between (a) what coming to learn the truth about personal identity gives us reasons to do and (b) how realising the truth about personal identity changes our affects, emotions, priorities, and behaviour. Parfit, it is important to emphasise, made two claims concerning personal identity and egoism. In the language of this paper, he asserted both that rejecting SVS forces us to reject rational egoism, thereby creating more room for rationally defensible altruistic action, and that changing his view about personal identity at a deeper level had certain psychological effects on him. He describes these effects as follows:

[Formerly] I seemed imprisoned in myself. My life seemed like a glass tunnel, through which I was moving faster every year, and at the end of which there was darkness. When I changed my view, the walls of my glass tunnel disappeared. I now live in the open air. There is still a difference between my life and the life of other people. But the difference is less. Other people are closer. I am less concerned about the rest of my own life, and more concerned about the lives of others (Parfit 1984, 281).

As Sean Smith recently noted in the pages of this journal $(2021,164-5)$, this report is highly congruent with the practical-ethical goals of Buddhism (a fact which Parfit was well aware of). The Buddhist account, however, suggests that the metaphysics of personhood may, in and of themselves, be independent of our ethical stance vis-à-vis self and other. It is not because I hold SVS that I am selfish; indeed, most selfish people hold no particular view in the philosophy of personal identity. It is VSS - not SVS that is tied up with my sense that I am what matters most in the world, with all that this entails by way of practical deliberation and action. Accordingly, the emphasis in Buddhism lies squarely on the transformative power of overcoming VSS, not on the (empirically dubious, and arguably naïve) hope that rejecting SVS will make people 
see reasons to act in certain ways, which their commitment to SVS previously prevented them from seeing. ${ }^{30}$ So while the jury may be still out on whether SVS grounds rational egoism - with the implication that the falsity of SVS makes rational egoism indefensible - it may nevertheless be true that people become less selfish and more impersonally concerned with other people's welfare as they learn to overcome VSS.

If further enquiry revealed that Buddhists were right about the benefits for and ethically desirable effects on the subject of learning to overcome VSS, this would entail that even if personal identity, theoretically considered, turned out to have no bearing on practical, prudential, and ethical reasoning, people might nevertheless have both prudential and moral reasons to change their minds (in a deep sense) about personal identity. This result, if supported, would be more significant than most of what has so far emerged from the technical discussions characteristic of academic philosophical enquiry into the ethics of personal identity. It would imply that personal identity is ethically important, not just as a technical philosophical issue, but at a deep experiential and psychological level that speaks to all people's concerns, not just the professional philosopher's.

\section{ACKOWLEDGMENTS}

I wish to express my gratitude to Rohit Dalvi, Charles Goodman, Rajiv Kaushik, Boris Hennig, and the anonymous reviewers of Comparative Philosophy for providing me with constructive feedback on earlier drafts of this essay.

\section{REFERENCES}

Albahari, Miri (2006), Analytical Buddhism: The Two-Tiered Illusion of Self (New York: Palgrave MacMillan).

Albahari, Miri (2014), "Insight Knowledge of No Self in Buddhism: An Epistemic Analysis", Philosophers' Imprint 14: <http://hdl.handle.net/2027/spo.3521354. 0014.021>

Baxter, Donald L. M (1989), "Identity through Time and the Discernability of Identicals", Analysis 49.3: 125-31.

Brown, Kirk W.; Ryan, Richard M.; and Creswell, J. David (2007), "Mindfulness: Theoretical Foundations and Evidence for its Salutary Effects", Psychological Inquiry, 18.4: 211-37. <https://doi.org/10.1080/10478400701598298>

\footnotetext{
${ }^{30}$ If anything, what can be gleaned from Parfit's writing on this subject is that for some people, such as Parfit himself, sustained reflection on the flaws of SVS leads to a weakening of the affective components of VSS, but only temporarily, after which point one must "reconvince [one]self" anew in order to "stun" these ill-advised affects. "Some Buddhists", Parfit suggestively hypothesises, "may have found the answer" to achieving more permanent result $(1986,836)$.
} 
Collins, Steven (1982), Selfless Persons: Imagery and Thought in Theravāda Buddhism (Cambridge: Cambridge University Press).

DeGrazia, David (2005), Human Identity and Bioethics (Cambridge: Cambridge University Press).

de La Vallée Poussin, Louis (ed.) (1970; $1^{\text {st }}$ edition 1903-13 with 1'Académie impériale des sciences, St. Petersbourg), Mülamadhyamakakārikās [Root Verses of the Middle School] (Mādhyamikasūtras [Sūtras of the Mādhyamika System]) de Nāgārjuna, avec la Prasannapadā [Clear Words], commentaire de Candrakīrti (Osnabruck: Biblio Verlag).

Féer, Léon (ed.) (1888; $3^{\text {rd }}$ edition 1994), Samyuttanikāya [Connected Discourses], volume II (London: Pali Text Society).

Féer, Léon (ed.) (1890; $2^{\text {nd }}$ edition 1975), Samyuttanikāya [Connected Discourses], volume III (London: Pali Text Society).

Féer, Léon (ed.) (1894; $2^{\text {nd }}$ edition 1990), Samyuttanikāya [Connected Discourses], volume IV (London: Pali Text Society).

Fiordalis, David V. (ed.) (2018), Thinking with Pierre Hadot on Buddhism, Philosophy, and the Path (Berkeley, CA: Mangalam Press).

Gendler, Tamar S. (2008), “Alief and Belief”, The Journal of Philosophy 105.10: 63463. <https://doi.org/10.5840/jphil20081051025>

Gómez, Luis O. (1976), "Proto-Mādhyamika in the Pāli Canon", Philosophy East and West 26.2: 137-65. <https://doi.org/10.2307/1398186>

Hadot, Pierre (1981; $3^{\text {rd }}$ edition 2003 with Albin Michel, Paris), Exercices spirituels et philosophie antique [Spiritual Excercises and Ancient Philosophy] (Paris: Études augustiniennes).

Hardy, Edmund (ed.) (1900; $2^{\text {nd }}$ edition 1979). Anguttaranikāya [Numerical Discourses], volume V (London: Pali Text Society).

Hayes, Steven C., and Plumb, Jennifer C. (2007). "Mindfulness from the Bottom Up: Providing an Inductive Framework for Understanding Mindfulness Processes and their Application to Human Suffering", Psychological Inquiry 18.4: 242-8. $<$ https://doi.org/10.1080/10478400701598314>

Heppner, Whitney L., and Kernis, Michael H. (2007). “'Quiet Ego' Functioning: Complementary Roles of Mindfulness, Authenticity, and Secure High Self-esteem”, Psychological Inquiry 18.4: 248-51. <https://doi.org/10.1080/10478400701598330>

Hulin, Michel (1978). Le principe d'égo dans la pensée indienne classique : la notion d'ahamkāra [The Ego Principle in Classical Indian Thought: The Notion of Ahamkāra] (Paris: Collège de France).

Hume, David (1739-40; Lewis A. Selby-Bigge edition, revised by Peter H. Nidditch 1978), A Treatise of Human Nature (Oxford: Oxford University Press).

Jinpa, Thupten (2002). Self, Reality, and Reason in Tibetan Philosophy: Tsongkhapa's Quest for the Middle Way (London: RoutledgeCurzon).

Leary, Mark R., and Tate, Eleanor B. (2007), "The Multi-faceted Nature of Mindfulness", Psychological Inquiry 18.4: 251-5. <https://doi.org/10.1080/ 10478400701598355> 
Panaïoti, Antoine (2015), "Personal Identity and Buddhist Philosophy in the Western Cultural Context: A Plea for Greater Cosmopolitanism", Transcultural Psychiatry 52.4: 501-23. <https://doi.org/10.1177/1363461515573106>

Parfit, Derek (1982), "Personal Identity and Rationality", Synthèse 53.2: 227-41. $<$ https://doi.org/10.1007/BF00484899>

Parfit, Derek (1984; $2^{\text {nd }}$ edition 1987), Reasons and Persons (Oxford: Clarendon Press).

Parfit, Derek (1986), “Comments", Ethics 96.4: 832-72. <https://doi.org/ $10.1086 / 292802>$

Parfit, Derek (1998), "Later Selves and Moral Principles", in James Rachel (ed.), Ethical Theory II: Theories about How We Should Live (Oxford: Oxford University Press), 143-69.

Parfit, Derek (1999), "Experiences, Subjects, and Conceptual Schemes”, Philosophical Topics 26.1/2: 217-70. <https://doi.org/10.5840/philtopics1999261/245>

Pradhan, Prahlad (ed.) (1967), Abhidharmakośabhāsya [Commentary on the Compendium of Abhidharma] of Vasubandhu (Patna: K. Jawaswal Institute).

Ricœur, Paul (1990; $2^{\text {nd }}$ edition 2015 with Éditions Points, Paris), Soi-même comme un autre [Oneself as Another] (Paris: Seuil).

Ruegg, David S. (1977), "The Use of the Four Positions of the Catușoți and the Problem of the Description of Reality in Mahāyāna Buddhism", Journal of Indian Philosophy 5.1/2: 1-71. <https://doi.org/10.1007/BF00200712>

Schechtman, Marya (1996). The Constitution of Selves (London: Cornell University Press).

Schwitzgebel, Eric (2002), “A Phenomenal, Dispositional Account of Belief”, Noûs 36.2: 249-75. <https://doi.org/10.1111/1468-0068.00370>

Strawson, Galen (2008), "On 'Freedom and Resentment'", in Michael McKenna and Paul Russell (eds), Free Will and Reactive Attitudes: Perspectives on P. F. Strawson's 'Freedom and Resentment' (Farnham: Ashgate), 85-114.

Shastri, Chandrashekara (ed.) (1954), Nyāyabindu [Drop of Logic] of Dharmakīti (Vanarasi: Kashi Sanskrit Series).

Smith, Sean (2021). "Buddhist Modernism, Scientific Explanation, and the Self", Comparative Philosophy 12.1: 157-69.

Struhl, Karsten J. (2020), "What Kind of an Illusion is the Illusion of Self", Comparative Philosophy 12.1: 113-39. < <https://doi.org/10.31979/2151-6014 (2020).110208>

Tsong kha pa $\left(14^{\text {th }}\right.$ century B.C.E), Lamrin chenmo, trans. The Lamrim Chenmo Translation Committee, Joshua W. C. Cutler (ed.) (2004), The Great Exposition of the Stages of the Path to Enlightenment by Tsong-kha-pa, volume III (Ithaca, NY: Snow Lion Publications).

Yamamoto, Kosho (trans.) (1973-5). The Mahāyāna Mahāparinirvāna Sūtra [Great Sūtra of the Supreme Nirvāna], volumes I-III (Ube City: Karinbunko).

Westerhoff, Jan (2009), Nāgārjuna's Madhyamaka: A Philosophical Introduction (Oxford: Oxford University Press).

Williams, Paul (1989; $2^{\text {nd }}$ edition 2009), Mahāyāna Buddhism: The Doctrinal Foundations (New York, NY: Routledge). 
Wittgenstein, Ludwig (1921), Logisch-philosophische Abhandlung, trans. Charles K. Ogden, Frank P. Ramsey, and Ludwig Wittgenstein (1922), Tractatus LogicoPhilosophicus (New York, NY: Harcourt, Brace, and Company, inc.).

Zahavi, Dan (2005), Subjectivity and Selfhood: Investigating the First-person Perspective (Cambridge, MA: Massachusetts Institute of Technology Press). 